\title{
Secondary uranium in phosphorites and its relation to groundwater in Egypt
}

\author{
Adel A. DABOUS* \\ Department of Geological Sciences, Florida State University, Tallahassee, FL 32306-4100, U.S.A.
}

(Received June 5, 2002; Accepted February 17, 2003)

\begin{abstract}
The stratiform phosphorite deposits of Egypt, which are found in an east-west band between $24^{\circ}$ and $27^{\circ}$ north latitude, contain from 25 to $100 \mathrm{ppm}$ uranium, a significant portion of which can be shown to have been secondarily adsorbed from groundwater. This fraction is readily leachable in $0.2 \mathrm{~N} \mathrm{~K}_{2} \mathrm{CO}_{3}$ and in the Red Sea area has the same ${ }^{234} U /{ }^{238} \mathrm{U}$ activity ratio, 1.3 , as the $\mathrm{U}$ dissolved in the associated groundwater. Both the excess of ${ }^{234} U$ and the deficiency of ${ }^{230} \mathrm{Th}$ relative to ${ }^{238} \mathrm{U}$ shows that the leachable $\mathrm{U}$ was adsorbed within the last $250 \mathrm{ky}$. Secondary $\mathrm{U}$ with the same ${ }^{234} \mathrm{U} /{ }^{238} \mathrm{U}$ activity ratio also occurs in the Western Desert phosphorite, indicating that it too has been adsorbed relatively recently, even though the groundwater table today is well below the phosphatic strata. On the other hand, the leachable U in the intervening Nile Valley deposits has an activity ratio near 1.0, suggesting that those strata have been above the groundwater table for the last million years. The adsorption of $\mathrm{U}$ may not be entirely associated with the principal phosphate mineral, carbonate-fluorapatite (francolite), $\mathrm{Ca}_{5}\left(\mathrm{PO}_{4}, \mathrm{CO}_{3}\right)(\mathrm{F}, \mathrm{OH})$. Iron, organic and clay phases are also present in the phosphorite ore.
\end{abstract}

\section{INTRODUCTION}

Stratified phosphorite ore is important as an economic deposit in Egypt, with uranium as a potential economic by-product of phosphate production. There are three major mining areas: the Western Desert between the Kharga and Dakhla Oases, the Nile Valley near Idfu, and along the Red Sea between Safaga and Quesir (Fig. 1). These deposits yield ore containing $90 \%$ phosphate and from 25 to $100 \mathrm{ppm}$ uranium. Of lesser importance are phosphate deposits in the Sinai Peninsula, which are of lower grade and considered to be commercially insignificant. The total phosphate reserves in Egypt are estimated to exceed 3 billion tons (Notholt, 1985), and although their contained U would exceed 100,000 tons, recovery of $\mathrm{U}$ from Egyptian phosphorites is conducted only on an experimental basis by the Nuclear Materials Authority of the Egyptian government (Ali, 1990).
A recent review by Sharafeldin (1999) has summarized the uranium occurrences as well as the clay mineralogy of the Egyptian deposits. Dabous (1981), El Kammar and El Reedy (1984), Ahmed (1986), Tamish (1988), Mahdy (1989), and Ali (1990) have focused on the geochemistry of uranium in Egyptian phosphorites, while Kolodny (1981), Osmond et al. (1984), and Burnett and Veeh (1992) have reviewed the U-series disequilibria often exhibited by phosphorites. In recently deposited phosphorites 40 to 80 percent of the contained $U$ is in the +4 valence state, signifying mostly reducing conditions of deposition (Cathcart, 1978; Kolodny and Kaplan, 1970; Burnett and Veeh, 1992).

The radionuclides investigated during this study are part of the two natural decay series, of which ${ }^{238} \mathrm{U}$ and ${ }^{232} \mathrm{Th}$ are the parents (Fig. 2). The $\mathrm{U}$ content and uranium isotope activity ratio of ${ }^{234} U /{ }^{238} U(A R)$ has been found to be especially useful in the interpretation of the history of aqui-

*E-mail:dabous@quartz.gly.fsu.edu 


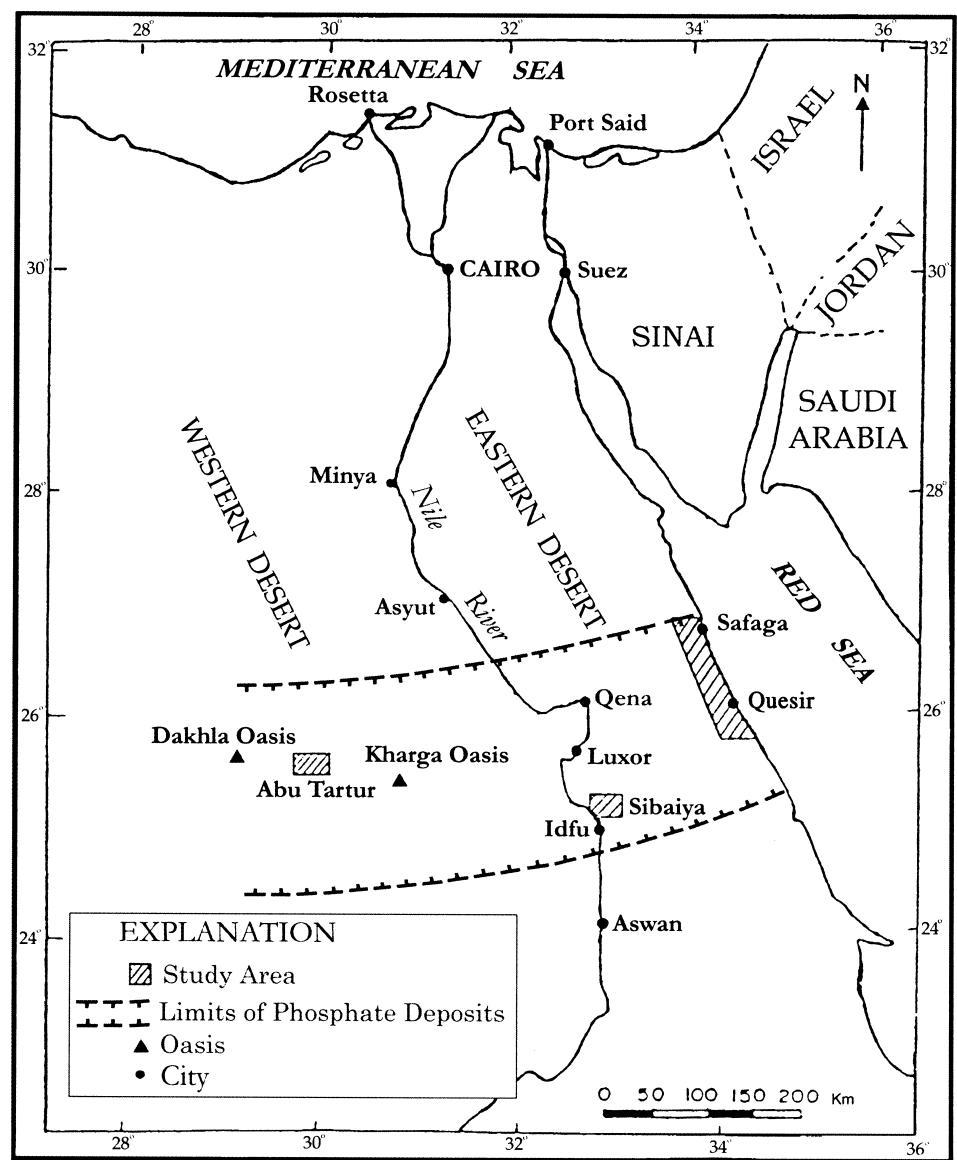

Fig. 1. Map of Egypt showing the location of the three studied mining areas; from West to East: Western Desert, Nile Valley, Red Sea.

fer waters and their leaching effects on the aquifer rocks (Osmond and Cowart, 2000).

It is the purpose of this study to examine the evidence for the presence of secondary uranium in the Egyptian phosphorites and to determine to what extent the timing of its adsorption from groundwater can be established.

\section{BACKGROUND}

\section{Geology and mineralogy}

The phosphorite ore deposits of Egypt are part of the Mediterranean Phosphate Province, which extends from Morocco to Turkey, and consists of strata deposited on the shallow Tethyan sea floor during Late Cretaceous and Early Tertiary time.
Over a band of Egypt between $24^{\circ}$ and $27^{\circ} \mathrm{N}$ latitude these strata are nearly horizontal but in the Red Sea area folding and block faulting have resulted in tilting of the mineable beds. The phosphate beds are estimated to contain in excess of 3 billion tons of ore (Notholt, 1985). Most of these reserves are in the Abu Tartur area.

In the region of the Eastern Desert (Red Sea Coast) the phosphorite-bearing strata are known as the Duwi Formation (Youssef, 1957), in the Nile Valley region as the Sibaiya Phosphate Formation (Youssef, 1957; El Nagger, 1966) and in the Western Desert as the Phosphate Formation (Awad and Ghobrial, 1966). These beds rest with seeming conformity on the Nubia sandstones and are overlain by the deeper water marls and chalks of 


\section{Z URANIUM-238 DECAY SERIES}

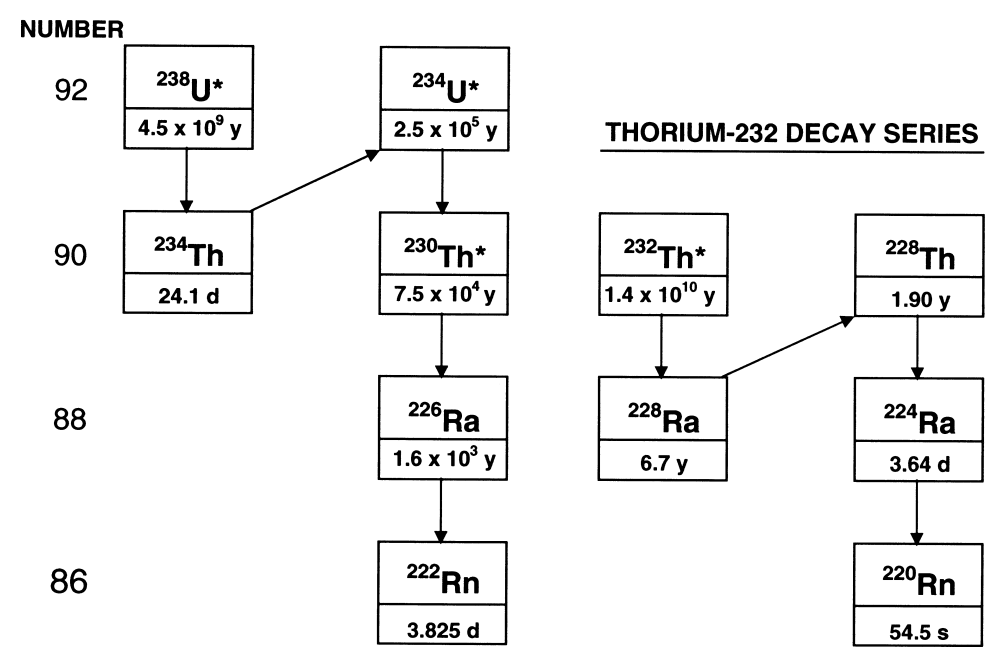

Fig. 2. The radioactive decay series of ${ }^{238} U$ and ${ }^{232} T h$. The asterisks indicate the four long-lived naturally occurring nuclides measured in this study. The uranium isotopes ${ }^{238} U$ and ${ }^{234} U$ were measured in all the groundwater and phosphorite samples. The thorium isotopes ${ }^{232}$ Th and ${ }^{230}$ Th were measured in the Red Sea phosphorites.

the Dakhla formation (Fig. 3).

The mineralogy of the Egyptian phosphorite deposits has been studied by many investigators (El Baz, 1970; Abu-Zeid, 1974; El Kammar, 1974; Kamel et al., 1977; Dabous, 1981; Sharafeldin, 1999). The major phosphorite mineral is carbonate-fluorapatite (francolite). The non-phosphatic minerals are represented by dolomite, calcite, quartz, pyrite, goethite, gypsum, smectite, and kaolinite. In the Western Desert palygorskite is recorded by Sharafeldin (1999) and wavellite is recorded by Kamel et al. (1977) and Shaaban and Dabous (1987).

The clay minerals associated with Egyptian phosphorites occur mainly as a matrix or as a filling of the intergranular pores. Some clay minerals are also present as parts of the phosphatic pellets, or as fillings of the cavity-like microstructures in the bone and teeth fragments. Smectite is the dominant clay mineral, followed by kaolinite, whereas illite and palygorskite are present in trace concentrations (Sharafeldin, 1999). Palygorskite occurs in the form of mats made up of ribbon-like fibers commonly associated with flaky smectite crystals that coat dolomite rhombohedra

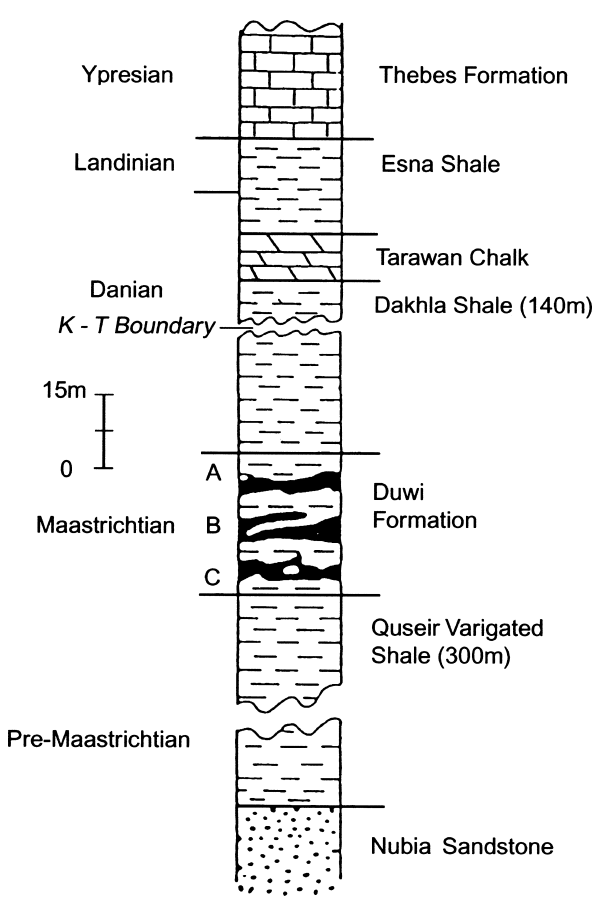

Fig. 3. General stratigraphic column of the QuesirSafaga district, showing the location of the phosphorite deposits. A, B, and $C$ are the major phosphorite seams of the Duwi Formation in the Quesir-Safaga area (after Said, 1990a). 
(Sharafeldin, 1999). This mode of occurrence has also been reported in the Miocene phosphorites of Florida (Van Kauwenbergh et al., 1990; Compton, 1997), the Cretaceous phosphorites of Morocco (Prevot, 1990), and the Jordanian Cretaceous phosphorites (Khoury et al., 1988).

The iron minerals goethite, hematite, and pyrite have been found as coatings on the outer surfaces of phosphate pellets and as parts of the cementing material (Dabous, 1981, Sharafeldin, 1999).

\section{HYDROGEOLOGY}

The general relationship of the Nubia Aquifer to the phosphate beds has been outlined by Dabous (1994). The depth to the water table of the Nubia Aquifer is more than $200 \mathrm{~m}$ at Kharga Oasis and more than $1000 \mathrm{~m}$ in the Nile Valley (Shata, 1982).

The hydrogeology of the Safaga-Quesir area in the Eastern Desert is described by Gomaa (1992), El Ghazawi and Abdelbaki (1991), and El Fakharani (1989). The mountainous area in the Eastern Desert is bisected by two sets of drainage lines, which conduct their water either to the Red Sea or to the Nile Valley. The Red Sea drainage set is included in the present study. This drains the Safaga-Quesir area, which includes the major basins of Safaga, Queh-Saqia, Ambagi-Abu Ziran and Essel, from north to south. The groundwater is tapped from different water-bearing formations, including alluvial deposits (Quaternary), sandstone deposits (Miocene-Oligocene), limestone deposits (Cretaceous), sandy gypsum-bearing shale-marl sediments (Cretaceous), and basement rocks.

The hydraulic gradient of groundwater in the limestone aquifer in the Duwi Formation decreases from north to south, from $+39.94 \mathrm{~m}$ to $+28.92 \mathrm{~m}$ above sea level. The water level in the same aquifer decreases in the southeast direction from $+46.26 \mathrm{~m}$ in the Queh mining area to $+22 \mathrm{~m}$ in the Abu Shigili mining area (Gomaa, 1992). The groundwater movement in the limestone aquifer is affected by the fault system that is located on the floor of the aquifer sediments. The dominant trend of this fault system is NNW-SSE parallel to the Red Sea graben (Issawi et al., 1969).

\section{Uranium geochemistry}

Uranium has two naturally occurring valence states. In shallow oxic-carbonate aquifers it has a +6 valence and is quite soluble as soluble carbonate complexes. In deep reducing aquifers it has a +4 valence and is generally insoluble. Host rocks containing phosphatic, argillaceaous, or organic material often behave as ion exchange media for otherwise soluble uranium. The most abundant isotope, ${ }^{238} \mathrm{U}$, is the decay chain parent of daughter ${ }^{234} \mathrm{U}$, and in closed systems older than $10^{6}$ years the two are in radioactive equilibrium, i.e., the ${ }^{234} \mathrm{U} /{ }^{238} \mathrm{U}$ alpha activity ratio is unity $(A R=1.00)$. However, because of enhanced mobilization of the daughter isotope by decay-related alpha recoil effects most ground waters have dissolved U with $A R$ 's greater than 1.00 , while many mineral surfaces and adsorption coatings have $\mathrm{U}$ with $A R$ 's less than 1.00. Therefore mobilization of $U$ often involves isotopic fractionation. On the other hand, precipitation or adsorption causes no fractionation and the secondary $\mathrm{U}$ will have the same $A R$ as the ground water source.

Once previously mobile $\mathrm{U}$ is incorporated into the solid phase, the excess ${ }^{234} U(A R-1.00)$ decays toward equilibrium according to its $250 \mathrm{ky}$ halflife.

\section{METHODS}

\section{Field collections}

Thirty-five ore samples were collected from the three principal phosphate mining areas in Egypt (Fig. 1): 12 samples from Abu Tartur (Western Desert), 12 from Sibaiya (Nile Valley), and 11 from Safaga-Quesir district (Red Sea coast).

The samples for this study were taken from the lower $4 \mathrm{~m}$ thick phosphate horizon in the Abu Tartur mining district of the Western Desert. In the Sibaiya mining district of the Nile Valley samples were also taken from the lower of two commercial beds. In the Safaga-Quesir (Red Sea) region, Said (1990a) has subdivided the Duwi For- 
mation into three phosphate horizons (A, B, and $\mathrm{C}$ of Fig. 3), each of which was sampled. The ore beds are tilted as a result of block faulting, and are lenticular rather than uniform in thickness (Hussein, 1990).

In addition twelve water samples were collected from the surficial aquifer of the Red Sea region, where the ore is largely below the water table. The water samples were collected in 4 liter plastic bottles, acidified with $20 \mathrm{ml}$ concentrated nitric acid, and filtered through a 0.45 microns pore-size filter.

\section{Mineralogy and chemical analyses}

The mineralogy of the phosphorite ore was determined by X-ray diffraction analyses (XRD), carried out at the Florida State University MARTECH laboratory, using a Siemens Diffractometer connected to DIFFRAC-AT software.

Total concentrations of $\mathrm{Ca}, \mathrm{P}, \mathrm{Fe}$, and $\mathrm{V}$ in 27 samples from the three mining areas were determined by Inductively Coupled Plasma Atomic Emission Spectrometry (ICP-AES). The analyses were performed at the Activation Laboratories, Ontario, Canada. A 0.25-gram aliquot of sample is digested in $10 \mathrm{ml}$ fuming $\mathrm{HClO}_{4}-\mathrm{HNO}_{3}-\mathrm{HCl}$ $\mathrm{HF}$ at $200^{\circ} \mathrm{C}$ and is then diluted to $10 \mathrm{ml}$ with dilute aqua regia. The solutions are read on a simultaneous Jarrell Ash ICP spectrometer. The precision of these analyses is $+/-5 \%$, all of the components being present at more than 100 times detection limits.

\section{Uranium and uranium isotopic analyses}

The ore samples were ground to pass a 230 mesh $(<63 \mu \mathrm{m})$ screen. Two grams were dissolved with $8 \mathrm{~N}$ hydrochloric acid, and the weights of the insoluble residue were determined. Another 2 grams were subjected to $0.2 \mathrm{~N} \mathrm{~K}_{2} \mathrm{CO}_{3}$ leaches at $\mathrm{pH}=12$ for 24 hours at $70^{\circ} \mathrm{C}$ (Weinberg and Cowart 2001). Previous leaching studies showed that apatite dissolution is not an important process (Roe and Burnett, 1985). The resulting analyzed phases of the phosphorites were designated as soluble (S), leachable (L), and soluble- unleachable $(\mathrm{F})$.

A known quantity of ${ }^{236} \mathrm{U}$ spike and a carrier consisting of ferric nitrate were added to each of the $S$ and $L$ samples. The samples were boiled and ammonia solution added for precipitation of ferric hydroxide. The resulting $\mathrm{Fe}(\mathrm{OH})_{3}$ floc is separated from supernatant liquid by centrifugation. The iron was separated from the actinides by solvent extraction with diethyl ether. The U was further purified by anion exchange procedures (Bio Rad AG $1 \times 8,100-200$ mesh). Both hydrochloric and nitric acid stages of anion exchange were used. The resulting purified and separated uranium was electroplated onto stainless steel planchets for counting by alpha spectrometry. Details of the procedures are given by Lally (1992). The uncertainty of both the $U$ concentration values and the $\mathrm{U}$ isotopic ratios was a uniform $+/-5 \%$, inasmuch as a fixed-count protocol was used.

Repeated calibrations were performed using an NBS marine phosphate standard (SRM-120C). Our result was uranium content of $115.0 \pm 4.6$ ppm, essentially identical to the reported value of $114.5 \mathrm{ppm}$ with a ${ }^{234} \mathrm{U} /{ }^{238} \mathrm{U}$ activity ratio of $0.92 \pm 0.03$.

After the water samples were evaporated, the dissolved uranium was determined by alpha specrometry in the same way as the ore samples.

\section{Thorium isotopic analyses}

The soluble phases of the Red Sea suite of phosphate samples were also analyzed for their thorium isotopic composition using ${ }^{229} \mathrm{Th}$ as a yield tracer. ${ }^{232} \mathrm{Th}$ is the more abundant common thorium isotope and ${ }^{230} \mathrm{Th}$ the radiogenic daughter of ${ }^{234} \mathrm{U}$ (Fig. 2). Because Th is insoluble under all natural ground water conditions, there should be very little original ${ }^{232} \mathrm{Th}$ in the phosphorite and any ${ }^{230} \mathrm{Th}$ should be the result of ingrowth following deposition. The dating equation derives from:

$$
\left(1-{ }^{230} \mathrm{Th} /{ }^{234} \mathrm{U}\right)=\exp (-\lambda t)
$$

where $\lambda$ is the decay constant of ${ }^{230} \mathrm{Th}(75 \mathrm{ky})$, and $t$ is the time since deposition of the $\mathrm{U}$. 
Table 1. Chemical data of the Egyptian phosphorites

\begin{tabular}{|c|c|c|c|c|c|c|c|c|}
\hline Sample number* & $\begin{array}{c}\mathrm{P}_{2} \mathrm{O}_{5} \\
\%\end{array}$ & $\begin{array}{c}\mathrm{CaO} \\
\%\end{array}$ & $\begin{array}{c}\mathrm{Fe}_{2} \mathrm{O}_{3} \\
\%\end{array}$ & $\begin{array}{c}\mathrm{V} \\
\mathrm{ppm}\end{array}$ & $\begin{array}{c}\mathrm{U}_{\mathrm{T}} \\
\mathrm{ppm}\end{array}$ & $\mathrm{U}_{\mathrm{L}}$ & $\mathrm{CaO} / \mathrm{P}_{2} \mathrm{O}_{5}$ & $\mathrm{U}_{\mathrm{T}} / \mathrm{P}_{2} \mathrm{O}_{5}$ \\
\hline W-01A & 37.11 & 44.67 & 5.12 & 67 & 25.9 & 2.6 & 1.20 & 0.70 \\
\hline $\mathrm{W}-02 \mathrm{~A}$ & 21.21 & 42.02 & 4.54 & 42 & 16.2 & 1.3 & 1.98 & 0.76 \\
\hline $\mathrm{W}-03 \mathrm{~A}$ & 32.01 & 44.99 & 4.61 & 64 & 23.5 & 2.5 & 1.41 & 0.73 \\
\hline $\mathrm{W}-04 \mathrm{~A}$ & 19.21 & 42.24 & 5.78 & 42 & 17 & 2.0 & 2.20 & 0.88 \\
\hline $\mathrm{W}-05 \mathrm{~B}$ & 29.03 & 44.33 & 6.01 & 56 & 22.8 & 2.8 & 1.53 & 0.79 \\
\hline $\mathrm{W}-06 \mathrm{~B}$ & 21.77 & 43.05 & 6.78 & 54 & 24 & 2.8 & 1.98 & 1.10 \\
\hline $\mathrm{W}-07 \mathrm{~B}$ & 23.02 & 43.01 & 4.76 & 48 & 21.5 & 1.9 & 1.87 & 0.93 \\
\hline W-08B & 26.11 & 43.92 & 2.99 & 59 & 23.4 & 0.8 & 1.68 & 0.90 \\
\hline W-09B & 33.98 & 44.21 & 5.01 & 59 & 22.6 & 2.3 & 1.30 & 0.67 \\
\hline W - MEDIAN & 26.11 & 43.92 & 5.01 & 56 & 22.8 & 2.00 & 1.68 & 0.79 \\
\hline $\mathrm{N}-01 \mathrm{C}$ & 27.33 & 49.34 & 2.21 & 66 & 53.9 & 0.0 & 1.81 & 1.97 \\
\hline $\mathrm{N}-02 \mathrm{C}$ & 27.32 & 49.11 & 2.31 & 74 & 53.5 & 0.2 & 1.80 & 1.96 \\
\hline $\mathrm{N}-03 \mathrm{C}$ & 28.85 & 48.44 & 2.37 & 73 & 59.8 & 0.3 & 1.68 & 2.07 \\
\hline $\mathrm{N}-04 \mathrm{C}$ & 26.42 & 47.33 & 3.99 & 75 & 53.3 & 24.5 & 1.79 & 2.02 \\
\hline $\mathrm{N}-05 \mathrm{C}$ & 21.21 & 41.81 & 1.41 & 49 & 42.3 & 0.0 & 1.97 & 1.99 \\
\hline $\mathrm{N}-06 \mathrm{C}$ & 29.99 & 49.89 & 2.77 & 77 & 64.7 & 1.9 & 1.66 & 2.16 \\
\hline $\mathrm{N}-07 \mathrm{C}$ & 25.99 & 44.55 & 2.31 & 71 & 45.9 & 0.0 & 1.71 & 1.77 \\
\hline $\mathrm{N}-08 \mathrm{C}$ & 31.01 & 48.85 & 2.17 & 69 & 63.5 & 0.7 & 1.58 & 2.05 \\
\hline $\mathrm{N}-09 \mathrm{C}$ & 31.66 & 49.32 & 2.44 & 74 & 63.2 & 0.1 & 1.56 & 2.00 \\
\hline $\mathrm{N}-10 \mathrm{C}$ & 30.34 & 48.89 & 2.01 & 75 & 64.2 & 0.1 & 1.61 & 2.12 \\
\hline $\mathrm{N}-11 \mathrm{C}$ & 25.12 & 42.01 & 1.71 & 58 & 52.9 & 1.4 & 1.67 & 2.11 \\
\hline $\mathrm{N}$ - MEDIAN & 27.33 & 48.85 & 2.31 & 73 & 53.9 & 0.2 & 1.67 & 2.02 \\
\hline R-01D & 31.02 & 47.78 & 2.01 & 143 & 119.8 & 1.7 & 1.54 & 3.86 \\
\hline R-02D & 26.11 & 50.99 & 1.65 & 93 & 100.2 & 1.5 & 1.95 & 3.84 \\
\hline R-03E & 21.21 & 45.91 & 1.84 & 87 & 60.2 & 1.1 & 2.16 & 2.84 \\
\hline R-04E & 30.77 & 52.01 & 0.63 & 131 & 120.1 & 0.3 & 1.69 & 3.90 \\
\hline R-05E & 24.89 & 45.01 & 1.11 & 112 & 93.3 & 1.1 & 1.81 & 3.75 \\
\hline R-06G & 24.88 & 47.83 & 2.31 & 101 & 109.8 & 2.1 & 1.92 & 4.41 \\
\hline R-07G & 22.51 & 46.78 & 1.99 & 107 & 112.2 & 1.6 & 2.08 & 4.98 \\
\hline R - MEDIAN & 24.89 & 47.78 & 1.84 & 107 & 109.8 & 1.00 & 1.92 & 3.86 \\
\hline
\end{tabular}

$U_{T}=$ Total uranium concentration in the whole sample, $U_{L}=$ Leachable uranium, $*=$ Sample locations are shown in Table 2. Note: Modal precision values are $+1-5 \%$.

\section{Phase data analysis}

The total uranium, in micrograms per gram of original phosphorite, was determined for the $\mathrm{S}$ (soluble) and the L (leachable) fractions, and that of the $\mathrm{F}$ fraction by difference:

$$
\mathrm{U}_{\mathrm{F}}=\mathrm{U}_{\mathrm{S}}-\mathrm{U}_{\mathrm{L}}
$$

(The $\mathrm{U}_{\mathrm{T}}$ values in Table 1 tend to be somewhat lower than the $\mathrm{U}_{\mathrm{S}}$ values in Table 2, because the former percentages are based on the whole ore samples, including the insoluble components.)
The ${ }^{234} \mathrm{U} /{ }^{238} \mathrm{U}$ activity ratio was also measured directly on the $\mathrm{S}$ and $\mathrm{L}$ fractions and that of the $\mathrm{F}$ fraction by differences, using the formula of Osmond and Cowart (1982):

$$
A_{F}=A_{S}-\left(U_{L} / U_{F}\right)\left(A_{L}-A_{S}\right)
$$

where $\mathrm{U}_{\mathrm{F}}$ and $\mathrm{U}_{\mathrm{L}}$ are the total $\mathrm{U}$ in the $\mathrm{F}$ and $\mathrm{L}$ phases; $A_{S}, A_{L}$, and $A_{F}$ are the activity ratios in the soluble, leachable, and non-leachable phases respectively. 
Table 2. Uranium concentration and activity ratio in phosphate phases

\begin{tabular}{|c|c|c|c|c|c|c|c|}
\hline \multirow[t]{2}{*}{ Sample number } & \multirow{2}{*}{$\begin{array}{c}\text { Per cent insoluble } \\
\text { residue }\end{array}$} & \multicolumn{3}{|c|}{$\mathrm{U}$ in phosphate (ug/g) } & \multicolumn{3}{|c|}{$\mathrm{U}$ activity ratio $\left({ }^{234} \mathrm{U} /{ }^{238} \mathrm{U}\right)$} \\
\hline & & $\mathrm{S}$ & $\mathrm{L}$ & $\mathrm{F}$ & $\mathrm{S}$ & $\mathrm{L}$ & $\mathrm{F}$ \\
\hline $\mathrm{W}-01 \mathrm{~A}$ & 6.5 & 27.7 & 2.6 & 25 & 1.03 & 1.08 & 1.02 \\
\hline $\mathrm{W}-02 \mathrm{~A}$ & 5.5 & 17.1 & 1.3 & 16 & 0.92 & 1.65 & 0.86 \\
\hline $\mathrm{W}-03 \mathrm{~A}$ & 9.0 & 25.8 & 2.5 & 23 & 0.94 & 1.73 & 0.84 \\
\hline $\mathrm{W}-04 \mathrm{~A}$ & 5.0 & 17.9 & 2.0 & 16 & 0.89 & 1.26 & 0.84 \\
\hline $\mathrm{W}-05 \mathrm{~B}$ & 14.7 & 26.7 & 2.8 & 24 & 1.01 & 1.25 & 0.98 \\
\hline $\mathrm{W}-06 \mathrm{~B}$ & 5.0 & 25.3 & 2.8 & 23 & 1.01 & 1.25 & 0.98 \\
\hline $\mathrm{W}-07 \mathrm{~B}$ & 6.0 & 22.9 & 1.9 & 21 & 1.03 & 1.40 & 1.00 \\
\hline W-08B & 9.3 & 25.8 & 0.8 & 25 & 1.00 & 1.39 & 0.99 \\
\hline W-09B & 6.7 & 24.2 & 2.3 & 22 & 1.01 & 1.25 & 0.98 \\
\hline W-10B & 9.7 & 4.1 & 0.3 & 4 & 1.10 & 1.62 & 1.06 \\
\hline $\mathrm{W}-11 \mathrm{~B}$ & 2.7 & 45.9 & 7.5 & 38 & 1.12 & 1.09 & 1.13 \\
\hline $\mathrm{W}-12 \mathrm{~B}$ & 7.7 & 22.9 & 0.0 & 24 & 0.96 & 2.10 & 0.96 \\
\hline W-MEDIAN & 6.6 & 25.0 & 2.0 & 23 & 1.01 & 1.35 & 0.98 \\
\hline $\mathrm{N}-01 \mathrm{C}$ & 6.5 & 57.6 & 0.0 & 58 & 1.05 & 1.00 & 1.05 \\
\hline $\mathrm{N}-02 \mathrm{C}$ & 5.7 & 56.7 & 0.2 & 57 & 1.01 & 2.00 & 1.01 \\
\hline $\mathrm{N}-03 \mathrm{C}$ & 9.4 & 66.0 & 0.3 & 66 & 1.03 & 0.98 & 1.03 \\
\hline $\mathrm{N}-04 \mathrm{C}$ & 5.6 & 56.4 & 24.5 & 32 & 1.04 & 1.04 & 1.04 \\
\hline $\mathrm{N}-05 \mathrm{C}$ & 0.4 & 42.5 & 0.0 & 44 & 1.00 & 1.34 & 1.00 \\
\hline $\mathrm{N}-06 \mathrm{C}$ & 9.1 & 71.1 & 1.9 & 69 & 1.14 & 1.01 & 1.14 \\
\hline N-07C & 37.4 & 73.4 & 0.0 & 75 & 1.18 & 1.07 & 1.18 \\
\hline $\mathrm{N}-08 \mathrm{C}$ & 9.3 & 70.0 & 0.7 & 69 & 1.03 & 1.03 & 1.03 \\
\hline N-09C & 9.8 & 70.1 & 0.1 & 70 & 1.01 & 1.08 & 1.01 \\
\hline N-10C & 2.8 & 66.0 & 0.1 & 66 & 1.01 & 1.11 & 1.01 \\
\hline $\mathrm{N}-11 \mathrm{C}$ & 26.9 & 72.3 & 1.4 & 71 & 1.07 & 0.89 & 1.07 \\
\hline N-MEDIAN & 9.4 & 66.0 & 0.2 & 65.9 & 1.03 & 1.04 & 1.03 \\
\hline R-01D & 4.4 & 125.2 & 1.7 & 124 & 0.99 & 1.99 & 0.98 \\
\hline R-02D & 2.4 & 102.7 & 1.5 & 101 & 1.14 & 1.25 & 1.14 \\
\hline R-03E & 0.9 & 60.7 & 1.1 & 60 & 1.09 & 1.15 & 1.09 \\
\hline R-04E & 3.6 & 124.6 & 0.3 & 124 & 0.98 & 1.56 & 0.98 \\
\hline R-05E & 3.9 & 97.1 & 1.1 & 96 & 1.02 & 1.46 & 1.01 \\
\hline R-06G & 2.2 & 112.2 & 2.1 & 110 & 1.01 & 1.23 & 1.01 \\
\hline R-07G & 1.2 & 113.6 & 1.6 & 112 & 1.04 & 1.26 & 1.04 \\
\hline R-08H & 2.4 & 54.7 & 0.0 & 55 & 1.02 & 1.20 & 1.02 \\
\hline R-09 I & 15.8 & 58.8 & 0.0 & 59 & 1.03 & 1.32 & 1.03 \\
\hline R-10J & 4.4 & 86.9 & 1.9 & 85 & 0.99 & 1.27 & 0.98 \\
\hline $\mathrm{R}-11 \mathrm{~J}$ & 2.5 & 94.6 & 1.9 & 93 & 1.01 & 1.32 & 1.00 \\
\hline $\mathrm{R}-12 \mathrm{~J}$ & 0.5 & 106.7 & 2.7 & 104 & 1.04 & 1.38 & 1.03 \\
\hline R-MEDIAN & 2.4 & 100.0 & 1.0 & 99.0 & 1.02 & 1.30 & 1.02 \\
\hline
\end{tabular}

KEY: $W=$ Western Desert, $N=$ Nile Valley, $R=$ Red Sea, $S=$ soluble, $L=$ leachable, $F=$ unleached, $A=$ Abu Tartur Old Mine, $B=$ Abu Tartur New Mine, $C=$ Sibaiya Mine, $D=U m$ El Huwitat Mine, E = South Rabah Mine, G = Mohamed Rabah Mine, $H=$ Quesir Old Mine, $I=$ Abu Shigli Mine, $J=$ Queh $3 H$ Mine.

Note: Modal precision values are $+/-5 \%$.

\section{RESUlts}

\section{Mineralogy of the phosphorites}

Carbonate-fluorapatite (francolite) is the major phosphate mineral in the Egyptian deposits as reported by Dabous (1981). Contaminants present include such non-phosphatic Ca-bearing minerals as calcite, dolomite, and gypsum.

The presence of these contaminants is also indicated by the chemical analyses summarized in 

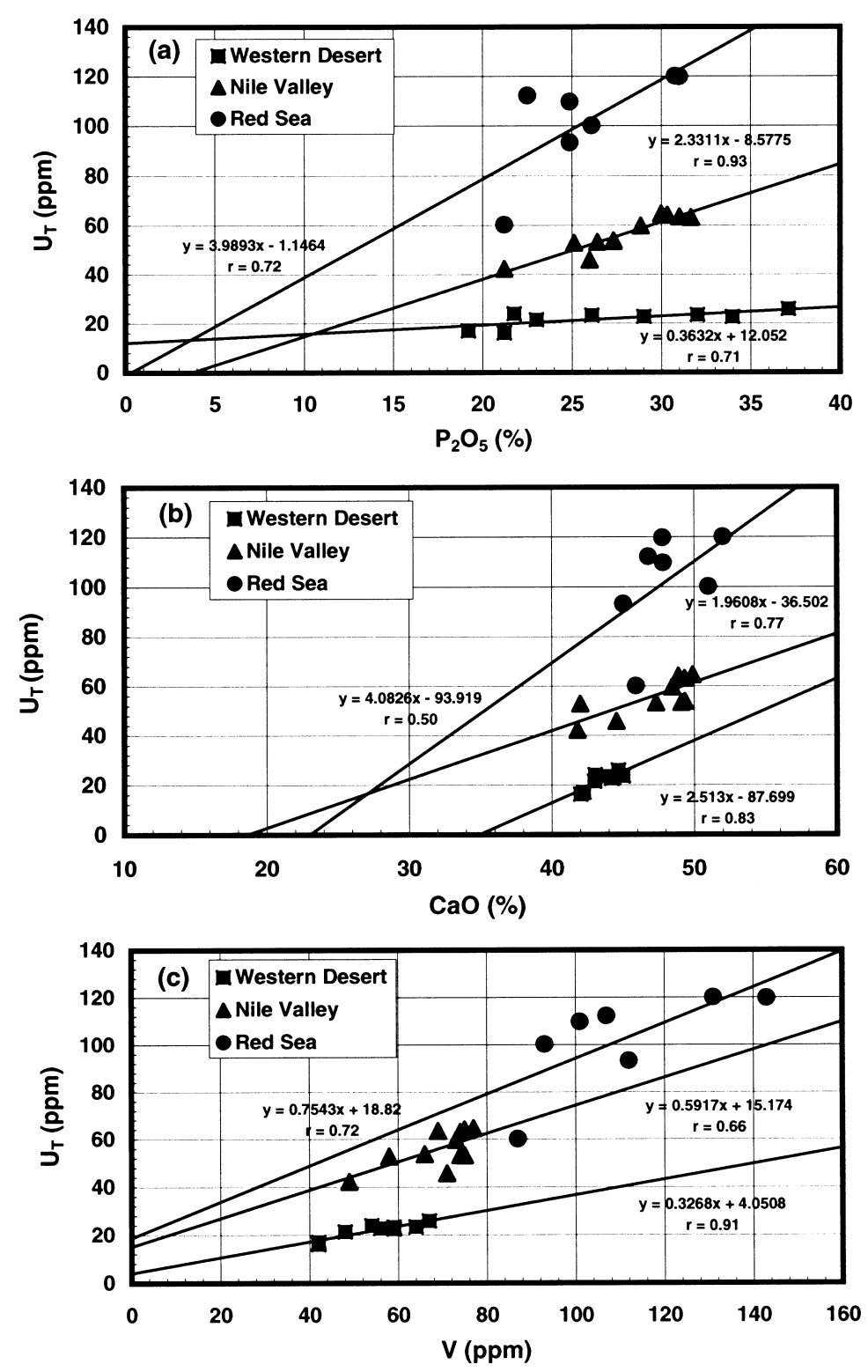

Fig. 4. Covariants of $U$ in Egyptian Phosphorites: (a) $U$ and $P_{2} O_{5}$. The linear covariations shown by all three sample suites show that the $U$ is associated with the phosphate minerals, with highest concentrations in the Red $S e a$ area, and least in the Western Desert. (b) $U$ and $\mathrm{CaO}$. The linear covariations show that the $U$ is associated with some Ca-bearing mineral such as francolite. That there is a significant non-zero intercept on the $x$-axis shows that there are other Ca minerals present which are not U-bearing, such as calcite, dolomite, and gypsum. The relative tenor of $U$ in the three areas is the same as in (a) above: Red Sea > Nile Valley > Western Desert. (c) $U$ and $V$. The linear covariation lines show that $V$ and $U$ are associated together in the phosphate minerals. The significant $y$-axis intercepts is indicative of secondary $U$ in the ore. 


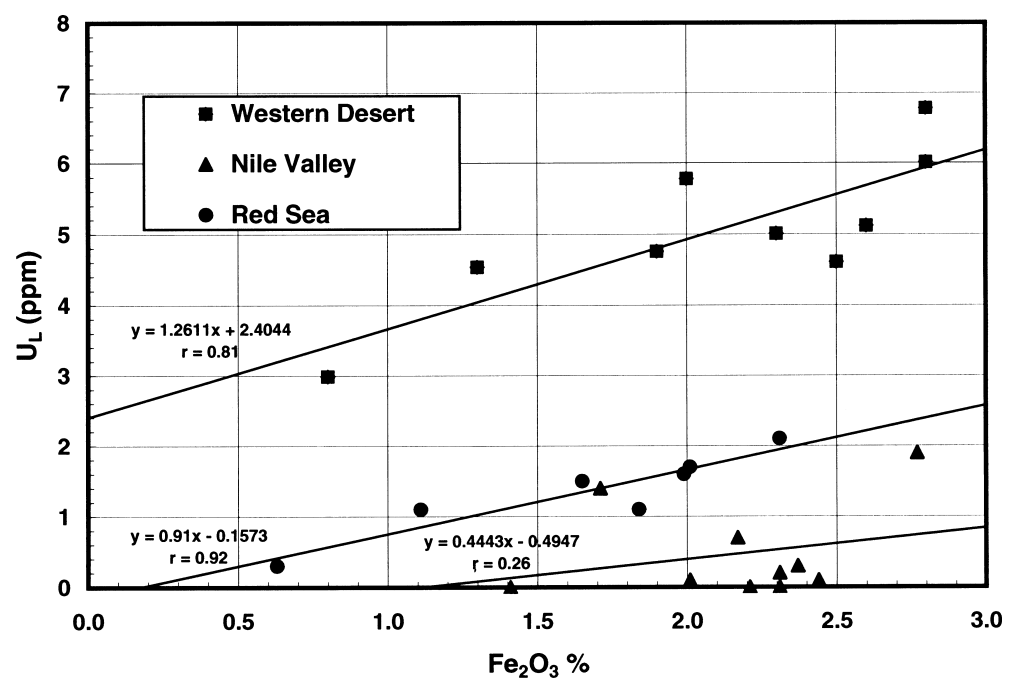

Fig. 5. The covariation of leachable uranium to iron content is especially strong in the Western Desert and the Red Sea samples, which suggests that the oxides of iron are adsorbing $U$ from groundwater. The Western Desert phosphorites, which have the least amount of total U (Fig. 4), have the largest amount of leachable U.

Table 1. The ideal CaO to $\mathrm{P}_{2} \mathrm{O}_{5}$ ratio for pure apatite would be 1.32 and could be as high as 1.55 in francolite depending on the amount of carbonate substituting for the phosphate radical (Dabous, 1981). The values for this ratio in the Egyptian phosphorites (1.67 to 1.92) is somewhat larger than expected and would be accounted for by the presence of calcite, dolomite, and gypsum. The highest ratio is observed in the Red Sea ores, where the X-ray diffractograms showed that the chief contaminant is calcite.

\section{Uranium in the phosphorites}

The concentration of uranium in the Egyptian phosphorites increases eastward, $25 \mathrm{ppm}$ in the Western Desert, 66 ppm in the Nile Valley deposits, and $100 \mathrm{ppm}$ in the Red Sea deposits (Table 2, Figs. 1 and 4). This is believed to be related in some way to the paleogeography of the Tethyan Seaway, but might also be coincidental.

That $\mathrm{U}$ is associated with the francolite is shown by its correlation with both $\mathrm{P}_{2} \mathrm{O}_{5}$ (Fig. 4a) and $\mathrm{CaO}$ (Fig. 4b). The non-zero intercept of the graph of $\mathrm{U}$ with $\mathrm{CaO}$ means that there is little association of $U$ with the non-phosphate minerals, calcite, dolomite and gypsum. The association of vanadium with $U$ (Fig. 4c) suggests that both elements are incorporated into the francolite lattice in similar fashion. On the other hand, iron, though often associated with $\mathrm{V}$ and $\mathrm{U}$, shows poor correlation with these two elements in the Egyptian phosphorites, suggesting the possibility that $\mathrm{Fe}$, like $\mathrm{U}$, is introduced later.

A broad peak on the X-ray diffractograms of the Red Sea samples indicates the presence of noncrystalline material, probably organics, which confirms the findings of El Kammar (1974) and Dabous (1981). This suggests the possibility that some of the uranium is adsorbed on organic material in the samples.

\section{$U$ in the leachable and unleachable phosphate phases}

Leaching of the phosphate ores with $\mathrm{K}_{2} \mathrm{CO}_{3}$ removes a measurable amount of $\mathrm{U}: 8 \%$ of the total $\mathrm{U}$ in the Western Desert samples, about $1 \%$ of that in the Red Sea samples, and $0.3 \%$ of the $U$ in the Nile Valley samples (Table 2). The uranium present in the Western Desert appears to be less concentrated but unusually soluble compared to that of the other two districts. In both the Western Desert and the Red Sea phosphorites there is a 

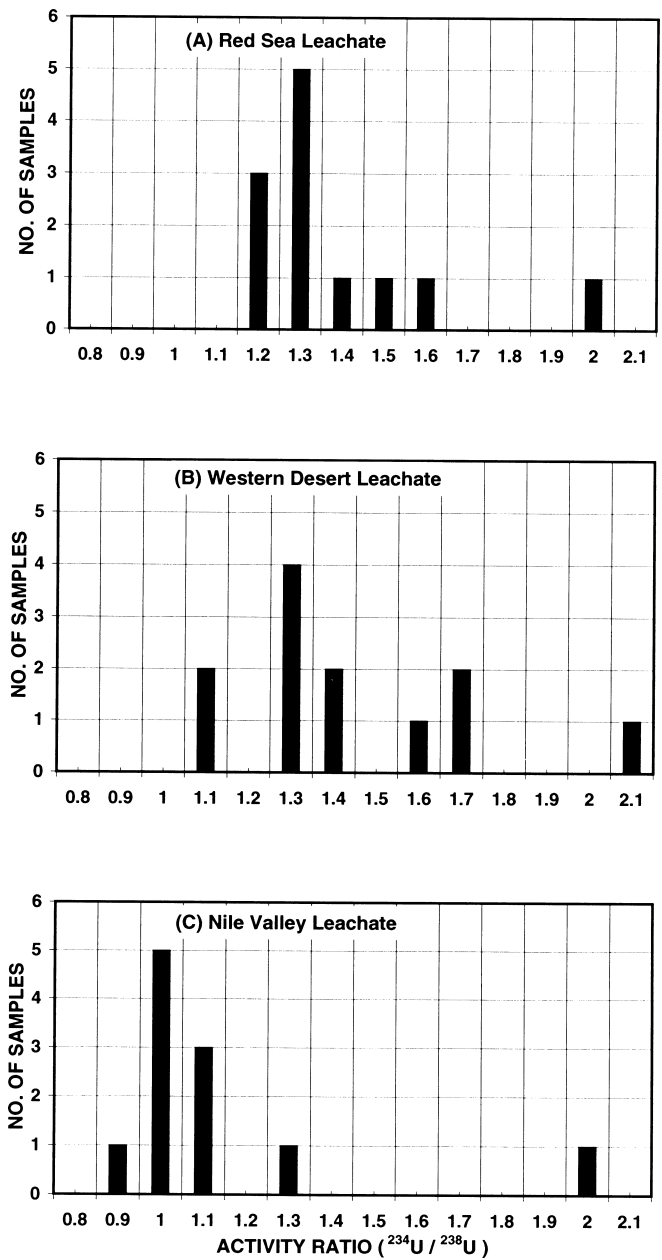

Fig. 6. Histograms of ${ }^{234} U{ }^{238} U$ activity ratio of leachate samples from the three study areas. The modal value for leachable $U$ activity ratio in the Western Desert and Red Sea areas is about 1.3. For the Nile Valley samples this value is close to 1.0 (equilibrium).

strong correlation between leachable uranium $\left(\mathrm{U}_{\mathrm{L}}\right)$ and $\mathrm{Fe}_{2} \mathrm{O}_{3}$ (Fig. 5). This suggests that oxides of iron could be acting as sorbants for uranium from groundwater. This leachable $\mathrm{U}$ has a ${ }^{234} \mathrm{U} /{ }^{238} \mathrm{U}$ activity ratio of about 1.3 which is distinctly higher than the unleached $U$ ratio of about 1.0 (equilibrium) in the case of the Western Desert and Red Sea phosphates. In the Nile Valley samples both the leachable and non-leachable $U$ has the activity ratio of equilibrium (Fig. 6).

These results contrast with leaching experi- ments on marine phosphate nodules which show no preferential extraction of U (Altschuler et al., 1958; Gavshin et al., 1973).

\section{Thorium in the soluble phosphate phase}

After removal of the resistate phases of the Red Sea samples, the soluble phosphate samples were analyzed for their thorium as well as uranium isotopic content (Table 3). As expected, the ${ }^{232} \mathrm{Th} /$ ${ }^{238} \mathrm{U}$ concentration ratio was quite low, making possible the measurement of a meaningful dating ratio, i.e., ${ }^{230} \mathrm{Th} /{ }^{234} \mathrm{U}$. Eight samples yielded ages ranging from 84 to $161 \mathrm{ky}$ and one $201 \mathrm{ky}$, while three proved to be more than $350 \mathrm{ky}$ old.

\section{Uranium in the groundwater of the Red Sea area}

Apparently the $U$ in the leachable phases has been adsorbed from groundwater at some time after initial deposition of the phosphate beds. This is proven by the considerable amount of $U$ adsorbed on the grain exteriors in all three areas, and the disequilibria of the adsorbed $U$ in the Red Sea and Western Desert areas. The phosphatic strata are tilted in the Red Sea area (Said, 1990a), so that in some places the ores are in contact with the groundwater below the present day water table. The concentration of $U$ in these groundwater is quite variable, from 0.024 to $22 \mathrm{ppb}$, but the ${ }^{234} \mathrm{U} /{ }^{238} \mathrm{U}$ activity ratio is consistently high (Table 4).

In Fig. 7 the activity ratio data is plotted against reciprocal $U$ concentration of the dissolved $U$ in the groundwater from the Red Sea area. This is a mixing-type diagram (Osmond and Cowart, 2000) which, if straight-line trends are observed, can be used to infer (a) the excess ${ }^{234} \mathrm{U}$ content of the groundwater and (b) the leaching activity ratio of the dissolved U. In the Red Sea area, three groundwater regimes can be identified, having disparate amounts of dissolved excess ${ }^{234} \mathrm{U}$, but a similar leaching ratio of 1.3 to 1.6.

That the leaching ratio of the dissolved $U$ in the Red Sea groundwater is identical to the leachable $\mathrm{U}$ of the phosphorite constitutes further confirmation that $\mathrm{U}$ is being exchanged between ore and water. The abundance of $U$ in the leachable 
Table 3. Thorium analyses and ${ }^{230} \mathrm{Th}^{234} \mathrm{U}$ ages of Red Sea secondary uranium

\begin{tabular}{lrrrcrrr}
\hline Sample number & $\mathrm{U}$ & $\mathrm{Th}$ & \multicolumn{3}{c}{ Activity ratios } & Age \\
\cline { 5 - 6 } & & & & & \\
\cline { 5 - 6 } & ppm & ppm & ${ }^{230} \mathrm{Th} /{ }^{32} \mathrm{Th}$ & ${ }^{234} \mathrm{U} /{ }^{238} \mathrm{U}$ & ${ }^{230} \mathrm{Th} /{ }^{34} \mathrm{U}$ & $\mathrm{ky}$ \\
\hline R-01D & 125.2 & 11.6 & 21 & 0.99 & 0.70 & 130 \\
R-02D & 102.7 & 4.6 & 30 & 1.14 & 0.66 & 118 \\
R-04E & 124.6 & 8.6 & 40 & 0.98 & 0.98 & $>350$ \\
R-05E & 97.1 & 1.5 & 126 & 1.02 & 0.66 & 118 \\
R-06G & 112.2 & 8.2 & 29 & 1.01 & 0.70 & 130 \\
R-07G & 113.6 & 5.5 & 34 & 1.04 & 0.54 & 84 \\
R-08H & 54.7 & 4.0 & 41 & 1.02 & 1.01 & $>350$ \\
R-09I & 58.8 & 10 & 22 & 1.03 & 0.71 & 134 \\
R-10J & 86.9 & 21.7 & 9 & 0.99 & 0.78 & 161 \\
R-11J & 94.6 & 3.6 & 66 & 1.01 & 0.84 & 201 \\
R-12J & 106.7 & 2.1 & 163 & 1.04 & 1.03 & $>350$ \\
\hline
\end{tabular}

Note: Modal precision values are $+1-5 \%$.

Table 4. Uranium isotopic data of groundwater in the Safaga-Quesir area of the Red Sea Region

\begin{tabular}{|c|c|c|c|c|c|c|}
\hline Locality & $\begin{array}{l}\text { Sample } \\
\text { number }\end{array}$ & Well designation & $\begin{array}{l}\text { Depth } \\
(\mathrm{m})\end{array}$ & $\begin{array}{l}\text { Uranium concentration } \\
\qquad(\mathrm{ppb})\end{array}$ & $\begin{array}{l}\text { Reciprocal } \\
\text { concentration }\end{array}$ & $\begin{array}{l}\text { Activity ratio } \\
\left({ }^{234} U{ }^{238} U\right)\end{array}$ \\
\hline \multirow[t]{5}{*}{ Safaga } & $1-\mathrm{A}$ & Um El Huwitat Mine & 150 & 6.739 & 0.15 & 1.58 \\
\hline & $2-\mathrm{A}$ & South Rabah Mine & 25 & 0.956 & 1.05 & 1.40 \\
\hline & $3-\mathrm{A}$ & Mohamed Rabah Mine & 17 & 2.457 & 0.41 & 1.25 \\
\hline & $4-\mathrm{A}$ & Wasif Mine & 一 & 0.143 & 6.98 & 2.83 \\
\hline & $5-\mathrm{A}$ & Queh-1 & 10 & 0.33 & 3.03 & 1.86 \\
\hline \multirow[t]{7}{*}{ Quesir } & $1-B$ & Queh 3 H Mine & 55 & 0.035 & 28.35 & 1.98 \\
\hline & $2-\mathrm{B}$ & Abu Shigli Mine & - & 0.065 & 15.43 & 1.63 \\
\hline & $1-\mathrm{C}$ & Queh-2H & 156 & 0.024 & 42.26 & 2.18 \\
\hline & $2-\mathrm{C}$ & Quesir Old Mine & 15 & 0.304 & 3.28 & 1.28 \\
\hline & $1-\mathrm{D}$ & Abu Spaq & 4.5 & 21.719 & 0.05 & 1.66 \\
\hline & $2-\mathrm{D}$ & Abu Korab & 4.6 & 5.284 & 0.19 & 1.69 \\
\hline & $3-\mathrm{D}$ & Ambagi Spring- 1 & - & 4.755 & 0.21 & 1.82 \\
\hline
\end{tabular}

$A=$ Limestone Aquifer (Duwi Formation, Safaga), B = Limestone Aquifer (Duwi Formation, Quesir), C = Sandstone Aquifer (Nubia Sandstone, Quesir), D = Alluvial Aquifer (Alluvial Deposits, Quesir).

Note: Modal precision values are $+/-5 \%$.

outer rinds of phosphate grains shows that the dominant process for the last million years $\left(\mathrm{T}_{1 / 2}\right.$ of ${ }^{234} \mathrm{U}=250 \mathrm{ky}$ ) has been adsorption.

\section{DISCUSSION}

\section{$U$ adsorption in the phosphorites}

The fact that a significant portion of the $U$, especially in the Red Sea district, is removable by gentle leaching shows that much of the $U$ in the Egyptian phosphorites is adsorbed rather than contained in the francolite lattice. The presence of iron in the analysis may indicate that, rather than the phosphorite itself, iron oxides may be the sites of adsorption. Borovec (1981) reports on experiments in which dissolved uranyl complexes are readily adsorbed on iron oxyhydroxides, organic matter, and montmorillonite clay. 


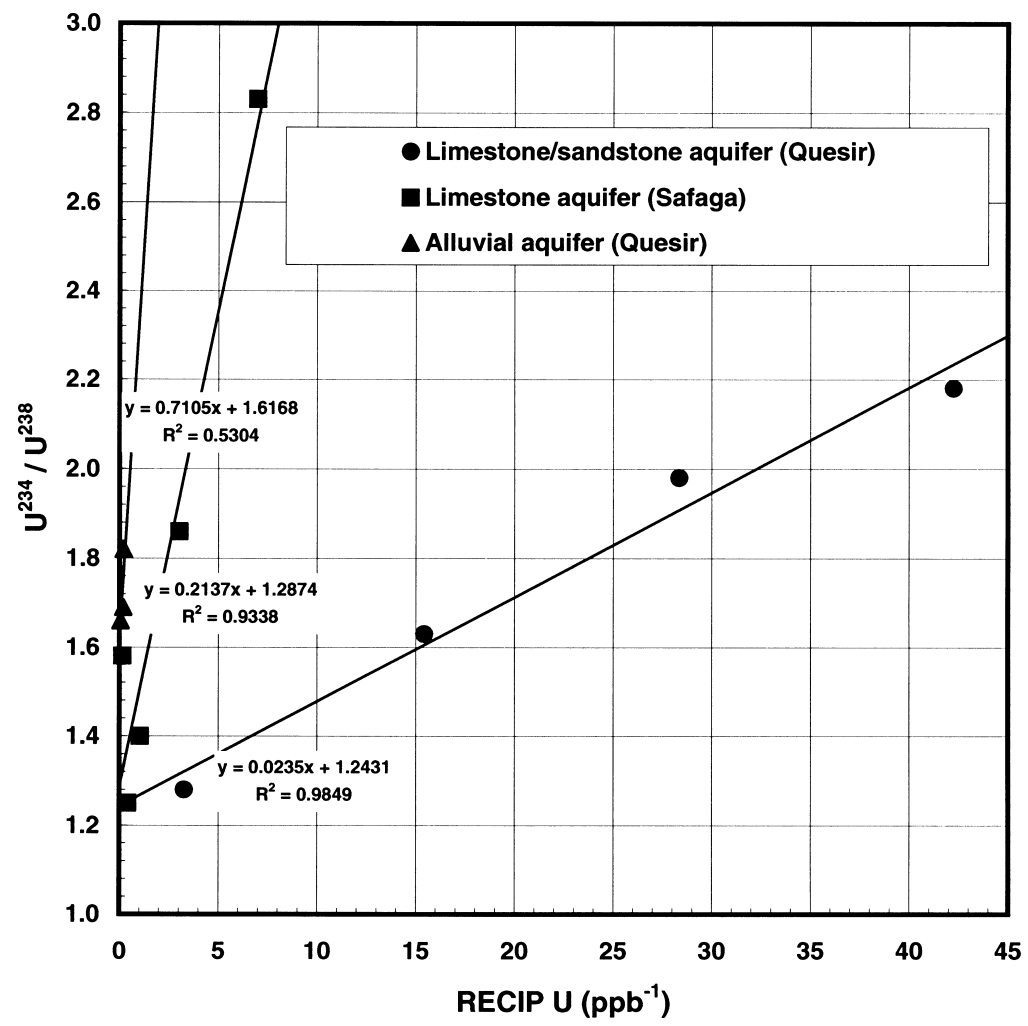

Fig. 7. Uranium isotopic mixing plot of the Safaga-Quesir groundwater. The three regression lines on this plot indicate possible water/rock interactions for three parts of the aquifer as a whole, the limestone aquifer near Safaga, the limestone/sandstone aquifer near Quesir, and the alluvial aquifer at Quesir. For each line the y intercepts show the ${ }^{234} U{ }^{238} U$ activity leaching ratio and the slopes the dissolved excess ${ }^{234} U$ in the aquifer waters. Of the three leaching systems the alluvial aquifer at Quesir has the highest concentration of excess ${ }^{234} U$, and the nearby deeper limestone/sandstone aquifer the lowest. The two strata-bound aquifers have the same indicated ${ }^{234} U{ }^{238} U$ leaching ratio at 1.24 to 1.29. The leaching intercept of the uranium in the alluvial aquifer is indicated to be higher, at 1.62, but given the uncertainty range of the intercept of this steeply sloping line it is not clear whether this leaching ratio is significantly different than the other two. All of the three leaching ratios are consistent with the activity ratios of the leachable uranium in the Red Sea phosphates (see A.R. histogram of Fig. 6).

On the other hand even the purest francolite samples analyzed here and elsewhere do contain $\mathrm{U}$, presumably somewhere in the lattice. That such $\mathrm{U}$ remains sensitive to the hydrologic environment is shown by the preponderance of $+6 \mathrm{U}$ in surficial island phosphorites (Roe and Burnett, 1985), and also in the oxidized groundwater of Florida (Upchurch and Randazzo, 1997; Weinberg and Cowart, 2001).

\section{Climatic History}

Changing climatic conditions over the last few million years in North Africa would have altered groundwater regimes episodically. For example the Sahara Desert was fertile, with abundant lakes, streams, and high groundwater tables only $8 \mathrm{ky}$ ago (Said, 1990b; Dabous and Osmond, 2001). Osmond et al. (1999) and Dabous (2002) have identified a pattern of leaching and redeposition associated with pluvial conditions in the $U$ and Fe deposits of the Egyptian Sahara. It is hypothesized here that the same climatic events have caused the changes in water table and the remobilization of $U$ in the phosphorites. 
The high $A R$ of the $\mathrm{U}$ in the Red Sea phosphorites, and also in the Western Desert phosphorites, as measured in this study, are an indication that the mobilization and redeposition of the $\mathrm{U}$ occurred relatively recently in terms of the half-life of ${ }^{234} \mathrm{U}, 250 \mathrm{ky}$. The ${ }^{230} \mathrm{Th} /{ }^{234} \mathrm{U}$ ages show that the time of this adsorption was mainly during oxygen isotope climatic stages 5 and 6,84 to $161 \mathrm{ky}$ (Table 3 ).

\section{Conclusions}

The $\mathrm{U}$ content of the Egyptian phosphorites varies from one mining locality to another with the highest concentration, $100 \mathrm{ppm}$, being found in the Red Sea deposits, and the lowest, 25 ppm, in the Western Desert deposits. About $8 \%$ of the uranium is readily leachable in the Western Desert, but less than $1 \%$ in the other two areas. The leachable $U$ has a ${ }^{234} \mathrm{U} /{ }^{238} \mathrm{U}$ activity ratio near 1.3 in the Western Desert and Red Sea deposits, but is close to the equilibrium value of 1.0 in the Nile Valley deposits. The Red Sea deposits occur partly within the local groundwater, which has a variable amount of dissolved U, up to $22 \mathrm{ppb} \mathrm{U}$, with an activity ratio of 1.3 . One can conclude from this that in the Red Sea region there is an active exchange of $U$ between the groundwater and the $\mathrm{U}$ adsorbed on some phases of the phosphorite. If the same process occurred in the Western Desert deposits, the groundwater table must have been lowered below the horizontal ore beds less than a million years ago. Conversely, the groundwater table in the Nile Valley mining district must have been lowered more than a million years ago.

Acknowledgments-I thank the Fulbright Commission in Cairo for the facilities offered to visit the phosphate mining areas in the Western Desert and the Red Sea. Also, thanks to Professor J. K. Osmond for his help in the field during sample collection, for critical review of the manuscript, and for his fruitful discussion. Thanks are extended to Dr. Erich Lochner, Analytic Facilities Administrator, Center for Materials Research Technologies, FSU, for help with the X-ray diffractometry. Financial assistance for this study was in part supplied by Grant EAR 94-18-212 of the National Science Foundation.

\section{REFERENCES}

Abu-Zeid, M. M. (1974) Contribution to the mineralogy and geochemistry of Variegated and Dakhla shales. Ph.D. Thesis, Ain Shams Univ., Cairo, Egypt, 249 pp.

Ahmed, F. Y. M. (1986) Uranium and vanadium distribution in Abu-Shegeila phosphates and their lithological and geochemical significance. M.S. Thesis, Mansoura Univ., Mansoura, Egypt, 137 pp.

Ali, M. M. (1990) The impact of the mineralogical and geochemical characteristics of West Sibaiya Nile Valley phosphorites on the extraction of uranium. Ph.D. Thesis, Cairo Univ., Cairo, Egypt, 163 pp.

Altschuler, Z. S., Clarke, R. S. and Young, E. J. (1958) Geochemistry of uranium in apatite and phosphorite. U.S. Geol. Surv. Prof. Paper 314D, 87 pp.

Awad, G. H. and Ghobrial, M. G. (1966) Zonal stratigraphy of Kharga Oasis. Annals of the Geological Survey of Egypt 34, 1-77.

Borovec, Z. (1981) The adsorption of uranyl species by fine clay. Chem. Geol. 32, 45-58.

Burnett, W. C. and Veeh, H. H. (1992) Uranium-series studies of marine phosphates and carbonates. Uranium Series Disequilibrium: Application to Environmental Problems (Ivanovich, M. and Harmon, R. S., eds.), 487-512, Oxford University Press.

Cathcart, J. B. (1978) Uranium in phosphate rock. U.S. Geol. Survey Prof. Paper 988-A, 8 pp.

Compton, J. S. (1997) Origin and paleoceanographic significance of Florida's phosphorite deposits. The Geology of Florida (Randazzo, A. F. and Jones, D. S., eds.), 195-216, Univ. Press of Florida, Gainesville.

Dabous, A. A. (1981) Mineralogy, geochemistry, and radioactivity of some Egyptian phosphorite deposits. Ph.D. Thesis, Florida State Univ., Tallahassee, Florida, 202 pp.

Dabous, A. A. (1994) The geochemistry of uranium and thorium isotopes in the Western Desert of Egypt. Geochim. Cosmochim. Acta 58, 4591-4600.

Dabous, A. . (2002) Uranium isotopic evidence for the origin of the Bahariya iron deposits, Egypt. Ore Geology Reviews 19, 165-186.

Dabous, A. A. and Osmond J. K. (2001) Uranium isotopic study of artesian and pluvial contributions to the Nubian aquifer, Western Desert, Egypt. J. Hydrol. 243, 242-253.

El Baz, M. H. (1970) Some economic aspects of phosphate deposits of Quesir area, Egypt. M.S. Thesis, Ain Shams Univ., Cairo, Egypt, 155 pp.

El Fakharani, M. A. H. (1989) Hydrology of Quesir area and its vicinities. M.S. Thesis, Cairo Univ., Cairo, Egypt, 107 pp.

El Ghazawi, M. M. and Abdelbaki, A. A. (1991) 
Groundwater in wadi Essel basin, Eastern Desert, Egypt. Bull. Faculty of Science, Menofiya Univ., Egypt 5, 25-44.

El Kammar, A. M. (1974) Comparative mineralogical and geochemical studies of some Egyptian phosphorites from Nile Valley, Quesir area and Kharga Oasis. Ph.D. Thesis, Cairo Univ., Cairo, Egypt, 425 pp.

El Kammar, A. M. and El Reedy, M. W. (1984) Geochemistry of uranium and some rare earth elements in the Cretaceous-Tertiary sediments of $\mathrm{Abu}$ Tartur, Western Desert, Egypt. Annals of the Geological Survey of Egypt 14, 75-86.

El Naggar, Z. R. (1966) Stratigraphy and classification of the type Esna Group in Egypt. Bull. Amer. Assoc. Petrol. Geologists 50, 1455-1477.

Gavshin, V. M., Bobrov, V. A., Pyalling, A. O. and Reznikov, N. V. (1973) The two types of uranium accumulation in rocks by sorption. Geochemistry International 10, 682-690.

Gomaa, M. A. (1992) Hydrogeological studies between Quesir-Safaga area, Eastern Desert, Egypt. M.S. Thesis, Ain Shams Univ., Cairo, Egypt, 172 pp.

Hussein, A. A. (1990) Mineral deposits. The Geology of Egypt (Said, R., ed.), 511-566, Rotterdam, A.A. Balkema.

Issawi, B., Francis, M., El Hinnawi, M. and Mehanna, A. (1969) Contribution to the structure and phosphate deposits of Quesir area. Geol. Surv. Egypt, Paper 50, $35 \mathrm{pp}$.

Kamel, O. A., Hilmy, M. E. and Bakir, R. (1977) Mineralogy of Abu Tartur phosphorites. Egypt. J. Geol. 21, 133-158.

Khoury, H. N., Al-Hawari, Z. Q. and El-Suradi, S. (1988) Clay minerals associated with Jordanian phosphates and their possible industrial utilization. Applied Clay Sci. 3, 111-121.

Kolodny, Y. (1981) Phosphorites. The Sea 7 (Emiliani, C., ed.), 981-1024, Wiley-Interscience, New York.

Kolodny, Y. and Kaplan, I. R. (1970) Uranium isotopes in sea-floor phosphorites. Geochim. Cosmochim. Acta 34, 3-24.

Lally, A. E. (1992) Chemical procedures. Uranium Series Disequilibrium: Application to Environmental Problems (Ivanovich, M. and Harmon, R. S., eds.), 95-126, Oxford University Press.

Mahdy, A. I. A. (1989) Geochemistry of uranium in some Egyptian phosphorite deposits around Sibaiya area, Nile Valley. M.S. Thesis, Ain Shams Univ., Cairo, Egypt, 136 pp.

Notholt, A. J. G. (1985) Phosphorite resources in the Mediterranean Tethyan Phosphogenic Province: A progress report. Sciences Geologiques Memoir 77, 9-21.

Osmond, J. K. and Cowart, J. B. (1982) Natural uranium and thorium series disequilibrium: New ap- proaches to geochemical problems. Nuclear Science Applications 1, 303-352.

Osmond, J. K. and Cowart, J. B. (2000) U-series nuclides as tracers in groundwater hydrology. Environmental Tracers in Subsurface Hydrology (Cook, P. and Herczeg, A., eds.), 145-174, Kluwer Academic Publishers, Boston.

Osmond, J. K., Cowart, J. B., Humphreys, C. L. and Wagner, B. E. (1984) Radioelement migration in natural and mined phosphate terrains. Florida Institute of Phosphate Research, Pub. No. 05-002-027.

Osmond, J. K., Dabous, A. A. and Dawood, Y. H. (1999) U-series ages and origin of two secondary uranium deposits, central Eastern Desert, Egypt. Econ. Geol. 94, 273-280.

Prevot, L. (1990) Geochemistry, petrography, genesis of Cretaceous-Eocene phosphorites: the Ganntour deposit (Morocco)-A type example. Soc. Geol. France, Memoire, No. 158, 232 pp.

Roe, K. K. and Burnett, W. C. (1985) Uranium geochemistry and dating of Pacific island apatite. Geochim. Cosmochim. Acta 49, 1581-1592.

Said, R. (1990a) Red Sea coastal plain. The Geology of Egypt (Said, R., ed.), 345-359, Rotterdam, A.A. Balkema.

Said, R. (1990b) Quaternary. The Geology of Egypt (Said, R., ed.), 487-510, Rotterdam, A.A. Balkema.

Shaaban, M. M. and Dabous, A. A. (1987) First record of wavellite and crandallite occurrence in Egypt, Bahariya Oasis. Middle East Research Center, Ain Shams Univ., Earth Science Series 1, 159-168.

Sharafeldin, A. A. (1999) Some geological aspects of the Egyptian phosphorites. Ph.D. Thesis, Ain Shams Univ., Cairo, Egypt, 294 pp.

Shata, A. A. (1982) Hydrogeology of the Great Nubian Sandstone Basin, Egypt. Quarterly Journal of Engineering Geology 15, 127-133.

Tamish, M. (1988) Geomathematical and geochemical studies on Egyptian phosphorite deposits. Berliner Geowiss. Abh. A98, Berlin, 97 pp.

Upchurch, S. B. and Randazzo, A. F. (1997) Environmental geology of Florida. The Geology of Florida (Randazzo, A. F. and Jones, D. S., eds.), 251-259, Univ. Press of Florida, Gainesville.

Van Kauwenbergh, S. J., Cathcart, J. B. and McClellan, G. H. (1990) Mineralogy and alteration of the phosphate deposits of Florida. U.S. Geol. Surv. Bull. 1914, $1-46$.

Weinberg, J. M. and Cowart, J. B. (2001) Hydrogeologic implications of uranium-rich phosphate in northeastern Lee County. Geology and Hydrogeology of Lee County, Florida (Missimer, T. M. and Thomas, M. S., eds.), 151-165, Florida Geological Survey Special Publication No. 49.

Youssef, M. I. (1957) Upper Cretaceous rocks in Quesir area. Bulletin de L'Institute de Egypt 7, 35-63. 